\title{
MONITORING GROWTH AND DEVELOPMENT OF TODDLERS ( 12 - 59 MONTHS) IN THE BALOI PERMAI PUBLIC HEALTH CENTER WORKING AREA, BATAM CITY
}

\author{
Bella Liany Putri, Iwan Stia Budi \\ Public Health Faculty Sriwijaya University, Jl.Palembang Prabumulih KM 32, \\ Indralaya District Ogan Ilir, South Sumatera 30662, Indonesia
}

\begin{abstract}
Toddlers are the age group that most often suffer from malnutrition and lack of nutrition. Based on data from the Batam City Health Office in 2017 regarding the scope of monitoring the growth and development of infants at $49.6 \%$ of the target set by the Ministry of Health of the Republic of Indonesia which is $80 \%$. Baloi Permai Public Health Center is the lowest public health center with 35.8\% achievement coverage. This study aims to analyze of monitoring growth and development of toodlers in the working area of Baloi Permai Public Health Center. The study design used qualitative methods. The number of informants in this study were 8 people. Data analysis using content analysis methods. The results of this study indicate that coordination of growth and development monitoring for toddlers is pooled interdependence, lack of standard operating procedure and standardization of skills. Indirect supervision in the form of recording and reporting has not been implemented. Coordination in monitoring the growth and development of toddlers in the working area of Baloi Permai Public Health Center is not optimal so it needs cooperation with related parties and the active role of all parties to reach the scope of growth and development of toddlers.
\end{abstract}

Keywords: Monitoring, growth, development, malnutrition, toddlers

\begin{abstract}
ABSTRAK
Balita merupakan kelompok rentan terhadap malnutrisi dan kurang gizi. Berdasarkan data dari dinas kesehatan Batam tahun 2017 capaian monitoring pertumbuhan dan perkembangan bayi sebesar $49.6 \%$ berada djauh dibawah target kementrian kesehatan yaitu 80\%. Puskesmas Baloi Permai merupakan puskesmas dengan capaian terendah yaitu 35.8\% cakupan. Penelitian ini bertujuan untuk menganalisis monitoring pertumbuhan dan perkembangan balita di wilayah kerja puskesmas Baloi Permai. Penelitian ini menggunakan desain studi kualitatif. Jumlah informan sebanyak 8 orang. Data dianalisis menggunakan metode analisis isi. Hasil penelitian ini menunjukkan bahwa koordinasi pemantauan tumbuh kembang balita masih saling ketergantungan, kurangnya standard operating procedure (SOP) dan standarisasi keterampilan. Pengawasan tidak langsung dalam bentuk pencatatan dan pelaporan belum diimplementasikan. Koordinasi dalam pemantauan tumbuh kembang balita di wilayah kerja Puskesmas Baloi Permai belum optimal sehingga perlu kerjasama dengan pihak terkait dan peran aktif semua pihak untuk mencapai cakupan tumbuh kembang balita.
\end{abstract}

Kata kunci : Monitoring, pertumbuhan, perkembangan, malnutrisi, balita

Correspondece Address: Iwan Stia Budi Jl. Palembang Prabumulih KM 32, Indralaya District Ogan Ilir, South Sumatera Email: iwans7777@gmail.com 


\section{Introduction}

Toddlers are the age group that most often suffer from malnutrition and lack of nutrition. ${ }^{1}$ According to World Health Organization, ${ }^{2}$ the number of malnourished sufferers in the world reaches 104 million children, a state of malnutrition in toddlers can also be found in developing countries, including in Indonesia. According toThe Ministry of Health, ${ }^{3}$ there were $19.6 \%$ of undernourished children consisting of $5.7 \%$ of toddlers with malnutrition, $13.9 \%$ lack of nutrition and $4.5 \%$ more nutrition. The results of the Nutrition Status Assessment ${ }^{4}$ stated that the percentage of malnutrition in children aged 0-59 months in Indonesia was 3.8\%, while the percentage of lack of nutrition was $14 \%$. According to the Health Profile of the City of Batam ${ }^{5}$ the prevalence of toddlers with a very thin category of $0.2 \%$ has decreased compared to 2014 which was $0.4 \%$.

Malnutrition in toddlers can have an impact on growth and development. ${ }^{6}$ Monitoring of toddler growth is very important to be done to detect early growth faltering. Based on the Profile of the Batam City Health Office, the coverage of monitoring the growth and development of toddlers is $49.6 \%$ of the target set by the Ministry of Health of the Republic of Indonesia which is $80 \%$ and the Baloi Permai Public Health Center has the lowest monitoring coverage of toddler growth and development which is $35.8 \%$. In order to increase the scope of monitoring the growth and development of toddlers requires coordination from various parties, namely the head of the public health center, the person in charge of the children's program, the implementing midwife and the health care ${ }^{5}$. This study aims to analyze of monitoring the growth and development of toddlers in Baloi Permai Public Health Center, Batam City.

\section{Method}

The research method used was descriptive qualitative research. This qualitative approach is used to obtain more in-depth information about the types of coordination, standardization (work processes, work results and skills), supervision, and communication in the implementation of monitoring the growth and development of toddlers (12 - 59 Months). Research informants are consisted of eight people, the Head of the Baloi Permai Public Health Center, the Child Program in charge of the Public Health Center, the village midwife and five health cadres who have criteria senior high school or above, one year cadre of member, good communication, and available to be a sample of research. The informant selection technique used purposive sampling method, a technique in which researchers have a tendency to choose which informants are considered to know information in depth relating to efforts to monitor the growth and development of toddlers in the working area of Baloi Permai Public Health Center. Collecting data or information is done by in- 
depth interview techniques with guidelines for in-depth interviews and observation and document review.

\section{RESULTS}

According to Thomson, ${ }^{7}$ the need for coordination is influenced by the level of dependence, standardization (work processes, work results and skills), supervision, and communication.

Based on the results of in-depth interviews it can be concluded that the coordination in monitoring the growth of toddlers is carried out when the posyandu activity is in charge of the children's program at the public health center bringing in village midwives then explains the main tasks and functions of village midwives as implementing and monitoring toddlers growth and development. "....If we found a toddler with delay growth and development, we tell to their parent first. But we also tell to the cadres because cadre closer to their parent..." (DAS)

While the coordination of the village midwife with the health care is the village midwife coordinating about the preparation of the posyandu activities the day before the activity. “....Midwife usually will give an information about the activity before the day of posyandu to the cadres" (PS)

The type of coordination between the person in charge of the child program with the village midwife and the coordination between the village midwife and the healthcare both have a pooled interdependence.

Standardization is very necessary when coordinating.

Work Process Standardization

Standardization of work processes needed in monitoring the growth and development of toddlers in the form of Standard Operating Procedure (SOP). Based on the results of in-depth interviews with the person in charge of the child program at the public health center said that they have SOP. "If you already know the SOP, for example, what kind of growth and development of the child Minister Of Health Regulation, how does it work also already have a reference to Minister Of Health Regulation, and that we write it in the form of SOP of Baloi Permai Public health center" (DM)

"... There is, if our work process is in a procedure that's already fixed, the name is SOP ..." (HH) Based on the document review of the SOP document by the researchers, it turns out that the document is not an SOP but a job description.

Standardize Work Results (Standardize outputs)

Output standardization is an effort to provide clear specifications of the performance produced. Based on the results of in-depth interviews, it was obtained that the Baloi public health 
center had a $90 \%$ coverage target for the monitoring and development program for toddlers. The work targets are stated in the decree of the head of the Batam City Health Office.

"... There, it means that SPM is from the PEMKO. If it's from the program $90 \%$ yes, but if it's from PEMKO $100 \%$... " $(\mathrm{HH})$

Other information states that not all informants know the standardization of work to be achieved.

Standardization of Skills and Knowledge

Efforts to standardize the ability of health workers in monitoring the growth and development of toddlers in the Baloi Community Public Health Center working area through training. Based on observations in the field of Baloi Community Public Health Center, there has never been any training related to the development of toddlers. The training that was done is APN (normal delivery care)

"... for midwives, nurses are functional, so we make a program to improve the quality of performance in accordance with the midwives, if the midwife is possible there is no APN training, we send midwives to attend training ..."

Likewise, efforts to standardize skills for health cadres have not been carried out, this is based on the results of field observations not found planning documents about health cadre training.

Supervision is one of the management functions to minimize the possibility of irregularities and efforts to make improvements or corrections can be done immediately.

“......Every posyandu program always have a midwife and nutritioner....”(NR)

“.....They also with us when the posyandu....”(PS)

Based on the results of in-depth interviews with informants the implementation of supervision which is direct supervision by the person in charge of the children's program by participating directly in the implementation of activities. Indirect supervision is also carried out in the form of reports on the results of activities to the person in charge of the children's program by the village midwife and supervision is not scheduled routinely and regularly.

\section{Communication}

Communication between the person in charge of the children's program and the village midwife has no communication routine and scheduled. Communication also takes place during the implementation of a mini public health center workshop.

"... because already know the schedule, so we already know each responsibility so we don't need to talk about it first ..." (HH)

"... Usually a mini workshop is held once a month, but the schedule can depend on the head of the public health center. 
"... non-formal communication regarding instructions for the preparation of posyandu activities the day before the activity through communication media, whatsapp group.

\section{Discussion}

Experience shows that malnutrition and ill health are traceable partly to economic causes, food availability and partly to educational factors. ${ }^{8}$ The research of Smock et $\mathrm{al}^{9}$ show that children with malnutrition may recover better by following participation in the special supplemental nutrition program. The level of dependency between the person who responsible in child program and the village midwife and the type of dependency between the village midwife and the health care are both pooled interdependent. Based on Thompson in Burton and Spender. ${ }^{10}$ a job will run optimally if there is interdependence in doing work (reciprocal interdependent), the existence of interactions that are interconnected each other in providing feedback, the work that has been produce and sequentially past the stages phrases which have been determined. Fitri research ${ }^{11}$ that the implementation of coordination in recording and reporting maternal and child health is needed to improve the effectiveness and efficiency of work, so that the division of tasks with the responsibilities of each employee is needed in order to produce outputs of proper recording and reporting time. Coordination at the levels of management, performing the functions of planning and forecasting innovation processes, analysis and evaluation functions, information and coordination support. ${ }^{12}$ The impact if coordination occurs between implementing midwives and cadres in the form of pooled interdependence coordination is that there is no reciprocal relationship between village midwives and health cadres, so the implementation schedule is not accordance with the community schedule, besides that if there are undesirable result from growth and development mentoring toddlers such as thin and very thin toddlers are not reported back to the village midwife so this cause the scope of growth and development mentoring for toddlers in Baloi Permai Public Health Center will far form target set.

Work process standardization, based on Sampara ${ }^{13}$ is a document or instrument that contains the process and the procedure of an activity that is effective and efficient based on a standard that has been standardized. Based on study shows that the implementation of growth and development mentoring activities for infants that occur in Baloi Permai Public Health Center has not been standardized the work process (SOP) which is reference in carrying out growth monitoring and development of infants but not only provide job descriptions in Baloi Permai Health. Regarding stimulation, detection and early intervention for toddlers development Benefits from the availability of standardized work process (SOP) in an organization of work result serves as a benchmark in determining the success of the Baloi Permai Public Health Center that not reached the target $(90 \%)$. This problem is caused by a wide working area but not supported by enough human resources, ${ }^{14}$ study shows that lack of human resources and high workloads lead to 
achievement of targets for service. ${ }^{15}$ Officers who have the competence make it possible for each type of work to carried out well, on time, on target. Based on Robins and Judge, ${ }^{16}$ Knowledge reflects and employee's cognitive ability to recognize, understand, realized and appreciate a job or task Job training method is a method which widely use in training the workforce. ${ }^{17}$ Based on result, there has been no effort to standardize skill monitor child growth and development. Training and development is an important organizational investment in human resources to gain knowledge and skills, so it can be used immediately at work. ${ }^{18}$

Supervision is a coordinating mechanism to measure what has been planned with what has been done directly and periodically to minimize irregularities. ${ }^{19}$ Direct supervision and periodically from leader to their staff make an easier to monitoring all activity in organization ${ }^{20}$ but indirect supervision has not been carried out such as monitoring and evaluating reports after the public health center (well known as posyandu) activities in Baloi Permai Public Health Center. Indirect supervision both trough oral report and written report must be considered by the leader. So it can be output for leader to know how their performances. ${ }^{21}$

Communication is the process of deliver a message or information that will be received by some or all members in a group or organization until the audience understood about the topic that we discussed. ${ }^{22}$ The result shows that communication between people who responsible in child program and the health care is in form of formal communication (mini public health center workshop meeting) and non-formal communication through Whatsapp message. Communication between officers is needed for prevent any misleading information, to coordinate and monitoring action the growth and toddlers development in Baloi Public Health Center. Ineffective communication between leaders and staff in an organization is the absence of work harmony and unity of coordination, so that it can affect the implementation of poor coordination and can hinder the process of achieving the goals or targets of the organization. ${ }^{23}$

\section{Conclusion}

The type of dependency in implementing growth monitoring and toddlers development in Baloi Public Health Center is pooled interdependence. This happened because the lack of feedback form village midwives and health care. So the implementation is not optimal. In addition, there are no operation standard procedure (SOP) so the indicators each place is different. Effort to improve staff skills and knowledge do not yet exist, so we have to equalize their understanding and perceptions of officers regarding the implementation for toddlers growth and development in Baloi Public Health Center such as to make SOP monitoring growth and development of toddlers on how to detect growth deviations that is measuring weight, height and measurement of head according to standard, further on how to detect developmental deviations, namely filling out preskening questionnaires development, hearing power tests, and viewing power tests, how to detect emotional 
mental irregularities. Planning training for implementing midwives and cadres on stimulation, detection and early invention of toddlers. Develop a web-based surveillance information system to find out the scope of monitoring the growth and development of toddlers in Baloi Permai Public Health Center, and have a formal meeting like monthly meeting.

\section{Acknowledgment}

Thanks to Batam City Health Office and the Baloi Permai Public Health Center for permission to carry out research and assistance during the research.

\section{Funding}

There is no funding for this research, and the funds used are the author's personal funds.

\section{Conflict of Interest}

There is no conflict of interest in this study.

\section{References}

1. Notoatmodjo. Ilmu Perilaku Kesehatan. Jakarta: PT. Rineka Cipta; 2010.

2. WHO. Preventing and Managing the Global Epidemic. Geneva; 2012.

3. The Ministry of Health. Basic Health Research. Jakarta; 2013.

4. Departemen Kesehatan RI. Riset Kesehatan Dasar. Jakarta; 2017.

5. Dinas Kesehatan. Profil Kesehatan Kota Batam. Batam; 2017.

6. UNICEF. The Current Situation of Children in The World. Jakarta; 2013.

7. Thompsons. Organizations in action: social sciences bases of administrative theory. New York: McGraw-hill Book Co; 1967.

8. Gulati JK. Child Malnutrition: Trends and Issues. Anthropol [Internet]. 1 April 2010;12(2):131-40. Tersedia pada: https://doi.org/10.1080/09720073.2010.11891143

9. Smock L, Martelon M, Metallinos-Katsaras E, Nguyen T, Cochran J, Geltman PL. Recovery From Malnutrition Among Refugee Children Following Participation in the Special Supplemental Nutrition for Women, Infants, and Children (WIC) Program in Massachusetts, 1998-2010. J Public Health Manag Pract [Internet]. April 2019; Tersedia pada: https://doi.org/10.1097/PHH.0000000000000995

10. Burton-Jones A S. The Oxford Handbook of Human Capital. In Oxford: Oxford University Press; 2012.

11. Melya Fitri Y, Sunarsih E, Stia Budi I. Koordinasi Pencatatan dan Pelaporan Kesehatan Ibu dan Anak di Public Health Center Wilayah Kerja Dinas Kesehatan Kota Padang. J Kesehat Tadulako. 2012;4(1):48-53. 
12. Guseva I, Dalekin P. Creation of Modern Region Innovation Infrastructure Development Management Techologies. Bull Lobachevsky State Univ Nizhny Novgorod. 2013;67.

13. Sampara. Pengaruh Penerapan Standar Operasional Prosedur Disiplin dan Komitmen Kerja terhadap Kinerja Pegawai pada Fakultas Teknik Universitas Hasanuddin Makassar. Hasanuddin; 2013.

14. Assegaai T, Schneider H. National guidance and district-level practices in the supervision of community health workers in South Africa: a qualitative study. Hum Resour Health [Internet]. 2019;17(1):25. Tersedia pada: https://doi.org/10.1186/s12960-019-0360-х

15. Siriyei I, Wulandari RD. Faktor Determinan Rendahnya Pencapaian Cakupan Standar Pelayanan Minimal Bidang Kesehatan di Public Health Center Mojo Kota Surabaya. Adm Kesehat Indones. 2013;1(1):244-51.

16. SP R, Judge. Perilaku Organisasi Buku. Jakarta: Salemba Empat; 2002.

17. Bangun W. Manajemen Sumber Daya Manusia. Cetakan Ke. Hani HT, editor. Yogyakarta: Erlangga; 2012.

18. Wibowo. Manajemen Kinerja. 3 ed. Jakarta: Rajawali Pers; 2013.

19. Al-adluny. Time Habit: Kebiasaan Efektif Mengelola Waktu. Yogyakarta: Pustaka Marwa; 2010.

20. Defi. Koordinasi Dalam Pengajuan Klaim Rawat Inap Tingkat Lanjut (RITL) Peserta Askes Sosial Di RSUP Moh. Husein Palembang Tahun. 2013.

21. Purwadi. Pengaruh Pengawasan Langsung dan Tidak Langsung terhadap Efektivitas Kerja Pegawai pada Dinas Pekerjaan Umum dan Pemukiman Prasarana Wilayah Kota Samarinda. Jurnal Administrasi Publik, 2017.

22. Daryanto. Teori Komunikasi. Malang: Gunung Samudera; 2014.

23. Yossy Melya Fitri, Iwan Stia Budi, Elvi Sunarsih. Koordinasi Pencatatan dan Pelaporan Kesehatan Ibu dan Anak Di Puskesmas Wilayah Kerja Dinas Kesehatan Kota Padang. Jurnal Kesehatan Tadulako. 2012. Suprapto. Komunikasi Organisasi. V. Jakarta; 2009. 